\title{
AÇAI (EUTERPE OLERACEA, MART.), AN AMAZONIAN FRUIT HAS ANTITUMOR EFFECTS ON PROSTATE CANCER CELLS
}

\section{Jobim ML}

Pharmacology Post-Graduation Program, Sciences and Health Program, Federal University of Santa Maria; Biogenomics Laboratory, Morphology Department, Center of Natural and Exact Sciences, Federal University of Santa Maria; Rua Roraima, 1000, Prédio 21, 97105900, Santa Maria, Rio Grande do Sul, Brazil; micheli.l.j@bol.com.br; https://orcid.org/0000-0002-7968-143X

\section{Barbisan F}

Gerontology Post-Graduation Program, Physical Education and Deport Center, Federal University of Santa Maria; Biogenomics Laboratory, Morphology Department, Center of Natural and Exact Sciences, Federal University of Santa Maria; Open University of Third Age, University of Amazon Estate.; fernandabarbisan@gmail.com; https://orcid. org/0000-0002-2960-7047

\section{Fortuna $M$}

Pharmacology Post-Graduation Program, Sciences and Health Program, Federal University of Santa Maria; Biogenomics Laboratory, Morphology Department; milena. fortunaz@gmail.com; https://orcid.org/0000-0003-0335-9994

\section{Teixeira CF}

Pharmacology Post-Graduation Program, Sciences and Health Program, Federal University of Santa Maria; Biogenomics Laboratory, Morphology Department, Center of Natural and Exact Sciences, Federal University of Santa Maria; cibelefteixeira@hotmail. com; https://orcid.org/0000-0003-0058-3827

\section{Boligon AA}

Federal University of Santa Maria, Health Sciences Center, Pharmacy Industrial Department; alineboligon@yahoo.com.br; https://orcid.org/0000-0002-6001-1313 


\section{Ribeiro EE}

Open University of Third Age, University of Amazon Estate; unatieuler@gmail.com https://orcid.org/0000-0003-3878-1933

\section{Da Cruz IBM}

Pharmacology Post-Graduation Program, Sciences and Health Program, Federal University of Santa Maria; Gerontology Post-Graduation Program, Physical Education and Deport Center, Federal University of Santa Maria; Biogenomics Laboratory, Morphology Department, Center of Natural and Exact Sciences, Federal University of Santa Maria; Open University of Third Age, University of Amazon Estate; ibmcruz@, hotmail.com; https://orcid.org/0000-0003-3008-6899

Abstract: Açai (Euterpe oleracea, Mart.) is fruit broadly consumed in the world. From its chemical matrix is possible that açai could has some cytotoxic effect against prostate cancer (PCa). To test this hypothesis using an in vitro PCa model DU145 cell. Additionally, potential synergism between açai and docetaxel (DO), a chemotherapic drug used to treat advanced PCa was also evaluated. Cells were exposed an açai hydro alcoholic extract at different concentrations ( 1 to $1000 \mu \mathrm{g} / \mathrm{mL}$ ) and its effect on viability, apoptosis and cellular proliferation was determined by MTT assay, growth cell, clonogenic assays and cell cycle analysis by flow cytometry. Differential modulation of $\mathrm{BCl}-2$ and $\mathrm{BAX}$ genes was also determined by Pcr quantitative in real time (qRT-PCR) analysis. Açai at lower concentrations (1-10 $\mu \mathrm{g} / \mathrm{mL})$ presented significant cytotoxic and antiproliferative action against PCa cells decreasing frequency of S phase cycle. Probably, this effect was associated with its strong down-regulation of $\mathrm{BCl}-2$ gene. However, açai did not contribute to improve Docetaxel effect's on PCa cells. Açai's PCa antitumor effects could be related to elevate concentrations of orientin plus vitexin, $p$-coumaric acid, apigenin and catechins present its chemical matrix, which are molecules with antitumor effect previously described in the literature.

Keywords: Carcinogenesis. DU145 cells. Antiproliferative. Nutrigenomics. Gene modulation.

\section{INTRODUCTION}

Prostatecancer(PCa) is themostincidentinelderlymen, however, its epidemiological distribution is heterogeneous, probably due environmental and genetic factors. In Brazil, Northern Region presents lower PCa prevalence than geographic regions. ${ }^{1}$ It is possible 
that differential nutritional patterns based in pre- Colombian diet rich in habitual fruit and fish consumption could have some protective role against $\mathrm{PCa} .^{2-5}$

A very popular fruit consumed in Northern region, as Amazonas State is açai (Euterpe oleracea, Mart.) that, nowadays is broadly consumed in other countries.6 This fruit has several bioactive molecules that could present PCa antitumoral property, such as epicatechin, quercetin and apigenin. ${ }^{7.8}$ From these evidences, we performed and in vitro assay to test potential açai effect against PCa cells and also its synergic effect with Docetaxel (DO) chemotherapic drug that is used to treat resistant PCa. ${ }^{9-11}$

\section{MATERIAL AND METHODS}

\subsection{PLANT MATERIAL, HYDRO ALCOHOLIC EXTRACT AND CHEMICAL CHARACTERIZATION}

The present study is part a project that has previous authorization by Brazilian Ministry of Environmental (no 012300.785152/6584-19) to investigate native species with potential biological impact on human health. Açai hydro alcoholic extract used here was the same produced and previously chemically characterized by Machado et al. ${ }^{12}$ The extract was obtained from fresh fruit açai samples from Manaus city, Amazonas, Brazil (3.080S, 60.010W).

The açai samples was used to produce the hydro alcoholic extract. The açai fruits were initially put in water during $24 \mathrm{~h}$ to become more soft and were crushed in a $70 \%$ ethanol solution with a concentration of $300 \mathrm{mg} / \mathrm{mL}$. To protect from light and humidity, the material was stored in amber bottles for 21 days under manual daily stirring. After this period of extraction, the material was initially filtered to remove the bark and seed, evaporated by a rotatory evaporator, and lyophilized to complete solvent removal, lyophilized and stored at $-200 \mathrm{C}$ until to perform the chemical characterization and in vitro studies.

Chemical characterization of 12 bioactive molecules was performed from açai extract by high performance liquid chromatography (HPLC) analysis using the Shimadzu Prominence Auto Sampler (SIL-2OA) system (Shimadzu, Kyoto, Japan). The freezedried 
Jobim ML et al.

hydroalcoholic extract was analyzed following the protocol reported by Klimaczewski et al.13 at $15 \mathrm{mg} / \mathrm{mL}$.

The analysis of bioactive molecules in açai extract tested here showed higher concentrations $(\mathrm{mg} / \mathrm{g})$ of orientin (8.05 \pm 0.03$)$ followed by apigenin $(3.59 \pm 0.01)$, p-Coumaric acid (3.52 \pm 0.01 ), cyanidyn-3-0-glucoside (2.62 \pm 0.01 ), epicatechin (2.37 \pm $0.02)$, luteolin ( $2.57 \pm 0.02)$ and vitexin (2.19 \pm 0.01$)$. Lower concentrations of caffeic acid (0.76 \pm 0.01$)$, catechin $(0.75 \pm 0.03)$, gallic acid $(0.73 \pm 0.01)$ and cholorogenic acid $(0.41 \pm$ 0.01) were also found in the extract.

\subsection{CELL CULTURE TREATMENTS}

The in vitro assays were performed using a DU-145 cell commercial line obtained from American Type Culture Collection (ATCC) and cultured in DMEM supplemented 10\% FBS, and $1 \%$ penicillin/streptomycin, maintained in incubator at $37{ }^{\circ} \mathrm{C}$ and saturation of 5\% CO2. Cells were exposed to different açai log-distributed concentrations (1, 3, 10, $30,100,1000 \mu \mathrm{g} / \mathrm{mL}$ ). The $100 \mu \mathrm{M}$ DO a chemotherapic drug, was used as a positive control in some tests. ${ }^{14}$ The synergism effect of açai extract and DO was also evaluated by concomitant treatment of cells with two components.

\subsection{CYTOTOXIC AND ANTIPROLIFERATIVE ACAI EFFECT}

Açai cytotoxic effects was evaluated in $24 \mathrm{~h}$ cell cultures and its antiproliferative effects in 48 and $72 \mathrm{~h}$ cell cultures by MTT assay (3-(4,5-dimethylthiazol-2-yl)-2,5diphenyltetrazolium bromide) spectrophotometric assay. ${ }^{15}$ Cytotoxic effect was confirmed by complementary protocol that analyzed necrosis and apoptosis açai's induction determined by flow cytometry using Annexin V: FITC Apoptosis Detection Kit obtained from Becton Dickinson-BD (East Rutherford, New Jersey, USA) as manufacturer`s instructions.

The antiproliferative effect of açai against PCa cells was confirmed by three complementary tests. Cell cycle analysis evaluated by flow cytometry in $72 \mathrm{~h}$ cell cultures using propidium iodide (PI) reagent as described in Azzolin et al. ${ }^{16}$ Cellular growth curve 
and clonogenic assays were performed as previously described by Cadoná et al. ${ }^{17}$ that use violet crystal dye to detect viable cells for 7 days. For the Clonogenic Assay were used cells/well in triplicate in the six well plates. The colonies were incubated until formatted 50 cells for colony (approximately 10-15 days). Further, colonies were detected with violet crystal and the number of colonies was counted as described Cubillos-Ros et al. ${ }^{18}$ Cell cycle analysis also evaluated by flow cytometry after the cells were treated for $72 \mathrm{~h}$ with açai extracts at different concentrations using PI reagent. ${ }^{16}$

\subsection{ACCAI EFFECTS ON GENES ASSOCIATED TO APOPTOSIS AND CELL PROLIFERATION}

Potential açai modulation on BAX (bcl-2-like protein 4) and Bcl-2 genes involving with the control of apoptosis and cellular proliferation was evaluated by Pcr quantitative in real time (qRT-PCR) analysis using RNA samples extracted with Trizol reagent and a general protocol previously described in Barbisan et al.19 Beta-actin gene was used as housekeeping gene to normalize the expression of $\mathrm{BAX}$ and $\mathrm{Bcl}-2$ genes. The relative expression was calculated using the comparative $\mathrm{Ct}$ and was expressed as the fold expression compared to the control. The primer pairs used were: BAX "FCCCTTTTCTACTTTGCCAGCAA", "R CCCGGAGGAA GTCCAATGT", Bcl-2 "FGAGGATTGTGGCCTTCTTTGAGT" and "R AGT CATCCACAGGGCGATGT".

\subsection{STATISTICAL ANALYSIS}

Treatments were compared by One-way ANOVA analysis of variance, followed by post hoc Dunnet or Tukey test, employing Graphpad Prism 5 software. The results were expressed as mean \pm standard deviation, with $p<0.05$ indicating statistical significance.

\section{RESULTS}

Some chemical molecules presented in the açai extract matrix could to be contributing with the antiproliferative activity of açai against PCa cells. A synthesis of some 
investigations that described antitumor effect of main bioactive molecules present in the açai extract tested here are presented in the Figure 1.

\begin{tabular}{|c|c|}
\hline Molecules & Main results \\
\hline Orientin and vitexin ${ }^{*}$ & PCa antitumor effect by increase of $\mathrm{BAX} / \mathrm{Bcl}-2$ ratio and activation of caspases. ${ }^{20}$ \\
\hline p-Coumaric acid & $\begin{array}{l}\text { Strawberry and honey present } \mathrm{p} \text {-Coumaric acid in their nutritional matrix present } \\
\text { PCa antitumor effect. }{ }^{21}\end{array}$ \\
\hline Apigenin & $\begin{array}{l}\text { Molecule found in parsley, celery, peppermint, cloves and red wine trigger } \\
\text { apoptosis in various PCa models }{ }^{22-24} \text { and shows synergistic effect in combinatorial } \\
\text { therapy of PCa resistant models and in the control of PCa stem cells. }{ }^{25}\end{array}$ \\
\hline Catechins\# & $\begin{array}{l}\text { These molecules are present in some species such as green, black tea and guarana } \\
\text { Robust evidences are demonstrated that green tea catechins are effective for } \\
\text { preventing PCa involving inhibition of Bcl-2 gene expression. }{ }^{25,26}\end{array}$ \\
\hline Cyanidin & $\begin{array}{l}\text { This molecule is able to presents anti-proliferative effects through activation of } \\
\text { caspase- } 3 \text { and induction of p } 21 \text { protein expression. PCa treatment with cyanidin } \\
\text { increased the levels of P75NGFR, a tumor suppressor molecule suggesting a } \\
\text { possible role of this molecule in the induction of a normal-like prostate cell } \\
\text { phenotype (differentiation induction). }{ }^{27}\end{array}$ \\
\hline Luteolin & $\begin{array}{l}\text { Molecule found in some foods, such as raw radicchio, chard, pumpkin, turnip and } \\
\text { some spices including dried oregano, yellow and green hot chili peppers is able } \\
\text { to inhibits cell proliferation of PCa cells. }{ }^{28} \text { Molecule presents suppressive effect } \\
\text { on DU145-III that presents great invasion potential. } .^{29} \text { Luteolin is also induces } \\
\text { apoptosis in PCa cells and inhibits cancer metastasis. }{ }^{30}\end{array}$ \\
\hline Phenolic acids\#\# & $\begin{array}{l}\text { These molecules are found in large number of vegetable foods, such as citric fruits, } \\
\text { apple, eggplant and food beverages as red wine and coffee. Cyclooxygenase-2 } \\
\text { (COX-2) expression is associated with increased cellular proliferation, prevents } \\
\text { apoptosis and favors tumor invasion. Gallic acid, a phenolic acid molecule is } \\
\text { able to inhibits COX-2 mRNA31 and induces apoptosis of PCa cells. }{ }^{32} \text { Effect of } \\
\text { caffeic acid inducing cell cycle arrestment and growth cell inhibition was also } \\
\text { reported. }{ }^{33} \text { Synthetic derivatives of caffeic acid are considered potent inhibitors } \\
\text { of proliferation of androgen-dependent prostate cancer cells. These molecules } \\
\text { also decrease of CPa cell variability. }{ }^{34} \text { A study also reported that caffeic acid was } \\
\text { able to enhance DO and paclitaxel cytotoxicity in PCa cells. }{ }^{35}\end{array}$ \\
\hline
\end{tabular}

Figure 1 - Description of some studies reporting antitumor effect against PCa of main bioactive molecules found in the açai hydro alcoholic extract

Note: " these molecules are flavonoids with similar chemical constitution; \# molecules that belong to the flavan3-ols (or simply flavanols) that are part of the chemical family of flavonoids; \#\# phenolic acids constituted by gallic, caffeic and chlorogenic acids presented in the chemical matrix of açai hydro alcoholic extract studied here.

Açai at lower concentrations tested here $(1,310 \mu \mathrm{g} / \mathrm{mL})$ was able to decrease PCa viability in comparison to controlgroup(Figure 2A,B). At contrary, highest açaiconcentrations $>100 \mu \mathrm{g} / \mathrm{mL}$ stimulated cells survival in $24 \mathrm{~h}$ cultures. All açai concentrations showed antiproliferative effect on PCa cells in 48 and $72 \mathrm{~h}$ cell cultures. However, this effect was more pronounced when cells were exposed to açai at $3 \mu \mathrm{g} / \mathrm{mL}$ concentration in $48 \mathrm{~h}$ cell cultures and at 1, $310 \mu \mathrm{g} / \mathrm{mL}$ concentrations in $72 \mathrm{~h}$ cell cultures. In general results did not showed a significant effect of açai and DO on apoptosis and necrosis events in the PCa 24 $h$ cell cultures $(p=0.067)$. 

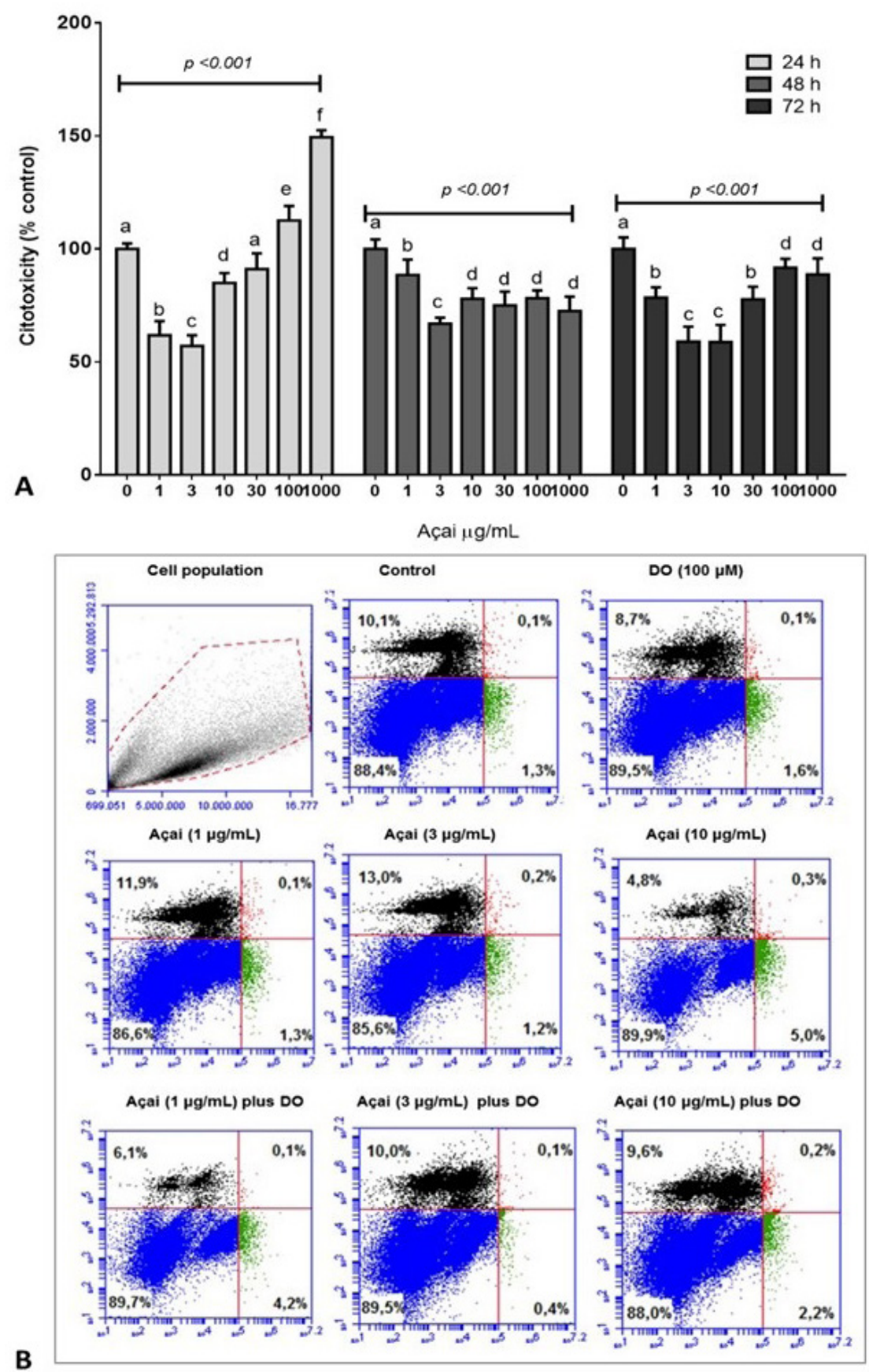

Figure 2 - (A) Comparison of antiproliferative effect on PCa cells in 24, 48 and $72 \mathrm{~h}$ cell cultures treated with açai (Euterpe oleraceae) hydro alcoholic extract. Different letters indicate statistical differences $(p<0.05)$ among treatments analyzed by One-way analysis of variance followed by post hoc Tukey test. (B) Comparison of apoptosis events evaluated by flow cytometry using Annexin $\mathrm{V}$ and propidium iodide dyes in $24 \mathrm{~h}$ culture of PCa DU145 cells treated with açai (Euterpe oleraceae) at different concentrations without (A) and with (B) concomitant treatment with docetaxel (DO) chemotherapic drug (representative graphs). Blue = viable cells; green = live cells undergoing early apoptosis; red = dead apoptotic cells; black = necrotic cells. 
Jobim ML et al.

Cell cycle analysis (Figure 4) showed that DO exposure increased cells in the G2/M phase when compared to control group, whereas açai increased the frequency of S phase cells. Both situations indicated differential modulation of PCa cell cycle. When cells where concomitantly treated with açai and DO, just cells treated with DO plus $3 \mu \mathrm{g} / \mathrm{mL}$ açai presented increase of frequency in the G2/M phase.

Açai at 1, 3 and $10 \mu \mathrm{g} / \mathrm{mL}$ concentrations presented a strong and significant down regulation effect on $\mathrm{Bcl}-2$ gene $(p=0.001)$ and this result was similar to found in cells just treated with DO chemotherapic drug: $\mathrm{DO}=0.0437 \pm 0.02$; açai $1 \mu \mathrm{g} / \mathrm{mL}=0.0374 \pm$ $0.02 ; 3 \mu \mathrm{g} / \mathrm{mL}=0.042 \pm 0.03,10 \mu \mathrm{g} / \mathrm{mL}=0.0307 \pm 0.02$ gene expressions in relation to control group. Despite different açai concentrations present up regulation effect on $B A X$ gene this effect was not so pronounced than observed in the $\mathrm{Bcl}-2$ gene $(p=0.01)$ : DO = $1.786 \pm 0.254 ;$ açai $1 \mu \mathrm{g} / \mathrm{mL}=1.230 \pm 0.219 ; 3 \mu \mathrm{g} / \mathrm{mL}=1.78 \pm 0.219,10 \mu \mathrm{g} / \mathrm{mL}=1.51 \pm 0.19$ gene expressions in relation to control group. $B A X / B C l-2$ gene ratio was higher 10 in cells exposed to DO and all açai concentrations confirming that antiproliferative effect on PCa cells involved biochemical pathways related with these genes (Figure 5). These results were similar when cells were concomitantly treated with DO and açai extract. 

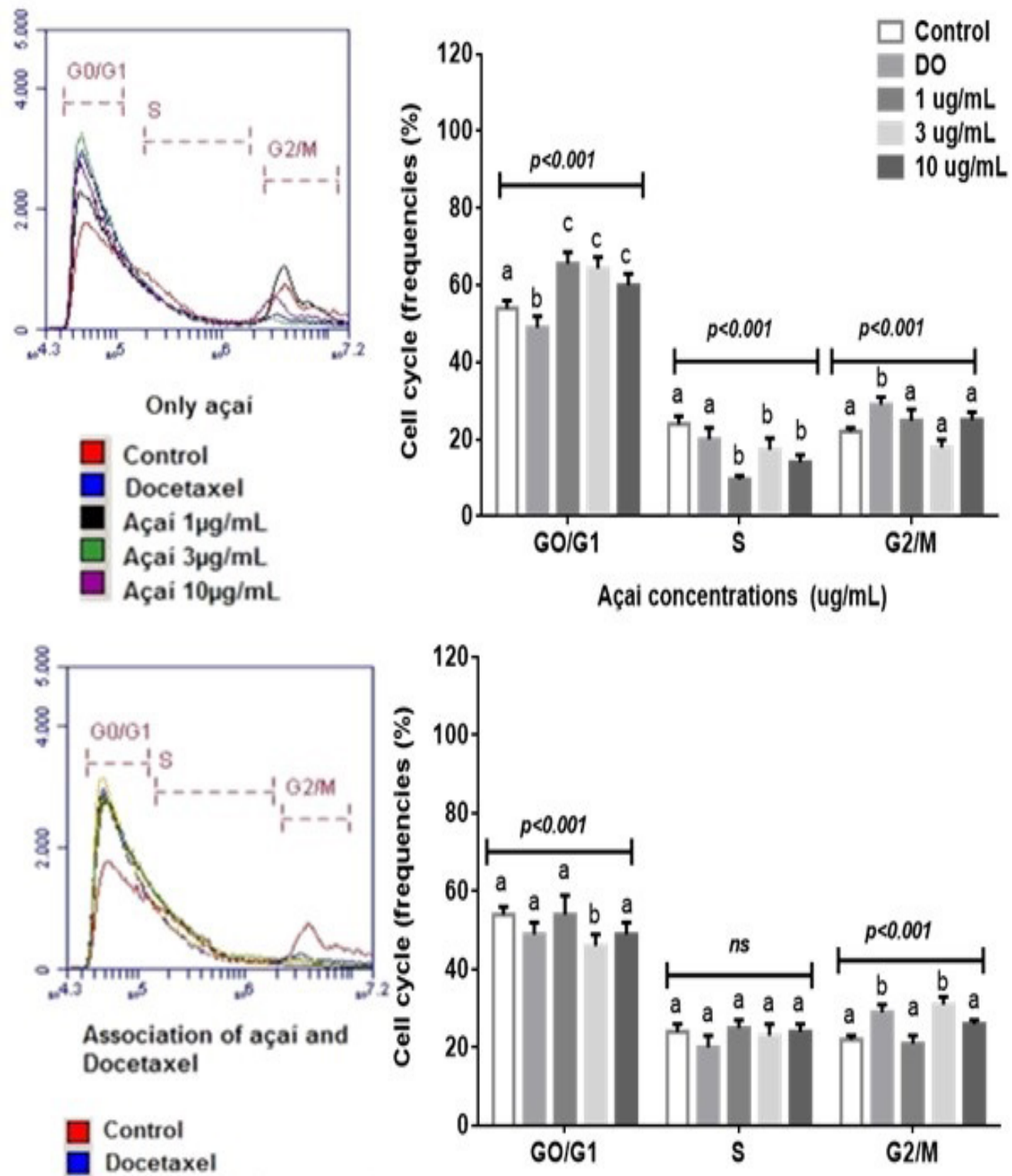

Docetaxel

Açai $1 \mu \mathrm{g} / \mathrm{mL}+$ Docetaxel Açai $3 \mu \mathrm{g} / \mathrm{mL}+$ Docetaxel Açai $10 \mu \mathrm{g} / \mathrm{mL}+$ Docetaxel

\section{Açai plus DO concentrations (ug/mL)}

Figure 4 - Comparison of cell cycle phases of PCa DU145 cells treated with açai (Euterpe oleraceae) hydro alcoholic extract at different concentrations. Different letters indicate statistical differences $(p<0.05)$ among treatments analyzed by One-way analysis of variance followed by post hoc Tukey test. 
Açai

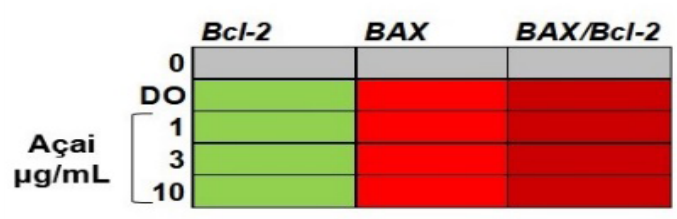

Açai plus DO

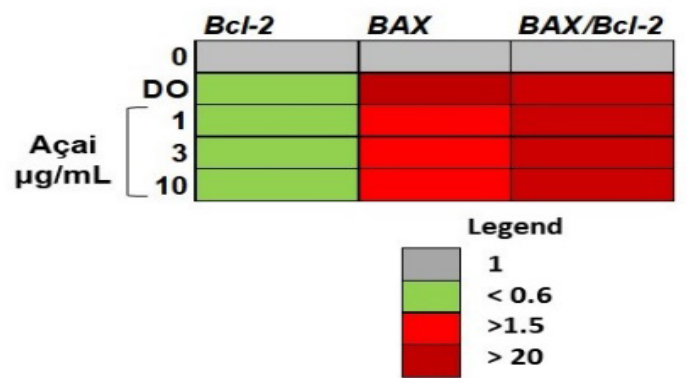

Figure 5 - Comparison of Bcl-2 and BAX gene expression of PCa DU145 cells treated with açai (Euterpe oleraceae) hydro alcoholic extract at different concentrations. Different colors indicate statistical differences $(p<0.05)$ among treatments analyzed by One-way analysis of variance followed by post hoc Tukey test. Gene expression values are represent by $1=$ similar to control; $<0.6=$ downregulation; $>1.5$ = upregulation; > 20 = upregulation.

\section{DISCUSSION}

The present study investigated the potential antitumoral effect of an açai hydro alcoholic extract on PCa cells. In general results showed that açai at concentrations ranged among 1 until $10 \mu \mathrm{g} / \mathrm{mL}$ presented a clear cytotoxic and antiproliferative action on PCa cells, similar to observed in cells DO exposed. Moreover, whole of results indicated that concomitant exposure did not affect the DO antitumoral action on cells. However, the interaction between DO and açai did not present a strong synergetic effect of antitumoral action of this chemotherapy drug. Evidence suggests that the anticarcinogenic efficacy of many foods is directly associated with the presence of secondary compounds, especially polyphenols. These molecules have several potentactivities, such as their anti-inflammatory and anti-inflammatory action, capable of modulating various cyto-histological functions, such as cell survival, proliferation, migration and differentiation, angiogenesis modulation, hormone response, detoxification and also the immune response. ${ }^{36}$

Gene expression analysis identify as mechanism that açai acts on PCa cells involves differential modulation of $\mathrm{BAX}$ and $\mathrm{Bcl}-2$ genes similar that is triggered by $\mathrm{DO}$. Despite methodological limitations related to in vitro protocols, for our best knowledgment this is the first study indicating potential antitumoral açai effects on PCa cells.

Orientin was the molecule with higher concentration in açai hydro-alcoholic extract tested here. In fact, this molecule is similar to vitexin and is also a water-soluble flavonoid 
C-glycoside of luteolin. These molecules are found in some spices and food beverages, such as black tea. ${ }^{21,37,38}$ Evidences has indicating that orientin has several biological properties ${ }^{39}$ including antitumor effect against human liver and esophageal cancer cells. ${ }^{38}$ In another study, a decrease in proliferative tumor markers in guinea-pig rats was observed, as well as annulment of inflammatory mast cells and decreased expression of $\mathrm{nF}-\kappa \mathrm{B}$ and proinflammatory cytokines. ${ }^{40}$ However, we found few studies suggesting that vitexin could has antitumoral effect against PCa cells. ${ }^{20,40,41}$ Therefore, the present study helps elucidate the potential antitumor effect in cancer cells, mainly prostate cancer.

p-Coumaric acid was the second metabolite more concentrated in açai extract. This phenolic acid serves a precursor of other phenolic compounds been found in some foods, such as strawberry and honey that present antitumor activity against PCa cells and other cancer cells. ${ }^{42-45}$

Undoubtedly, apigenin found in açai extract is the molecule that more number of studies suggest antitumor PCa effect. ${ }^{8}$ Studies related to causal mechanism associated with apigenin on PCa cells involve inhibition of androgen production. ${ }^{46}$ Other antitumoral mechanisms of apigenin in different cancer types include cellular arrestment by downregulation of telomerase activity and also suppressive effect of $\mathrm{Bcl}-2$ protein expression. ${ }^{23,47}$ Therefore, apigenin found in açai extract probably had an important role in the antitumor activity observed in PCa cells. This antitumor effect also could be accentuated by catechins and luteolin also found in the açai extract and that present capacity to modulate differentially $B A X$ and $B c l-2$ genes. ${ }^{48}$

\section{CONCLUSION}

In summary, despite methodological constrains related with in vitro studies, the results presented here suggest that açai extract has some antitumoral effect against PCa DU145 cells involving down-regulation of $\mathrm{BCl}-2$ gene. The synergism between açai and DO is not so effective, but it is not possible to discard that this interaction could to induce improvement in the DO cytotoxic property. The results presented here could considered novel and suggest that açai could be use nutritional supplement in order to prevent PCa or to progression of PCa disease. 


\section{CONFLICT OF INTEREST}

The authors declare that they have no conflict of interest.

\section{ACKNOWLEDGEMENTS}

We are grateful to Aline Augusti Bolignon, Alencar Kolinski Machado, Beatriz da Rosa Silva Bonadiman, and Andrielli Puhle, for give us the characterized açai extract tested here. This work was supported by grants and fellowships from Brazilian governamental funds: Fundação de Amparo a Pesquisa do Amazonas (FAPEAM), Fundação de Amparo a Pesquisa do Rio Grande do Sul (FAPERGs) and Conselho Nacional de Pesquisa e Desenvolvimento (CNPq).

\section{REFERENCES}

1. Oliveira MM, Malta DC, Guauche H, Moura L, Silva GA. Estimated number of people diagnosed with cancer in Brazil: data from the National Health Survey. Rev Bras Epidemiol. 2013; 18(2):146-9.

2. Lin $\mathrm{PH}$, Aronson W, Freedland SJ. Nutrition, dietary interventions and prostate cancer: the latest evidence. BMC Med. 2015; 13(3).

3. Zhou Y, Li Y, Zhou T, Zheng J, Li S, Li H. Dietary Natural Products for Prevention and Treatment of Liver Cancer. Nutrients. 2016; 8(3):156.

4. Boam T. Anti-androgenic effects of flavonols in prostate cancer. ECancer Medical Science. 2015; 9:585.

5. Dufour DL, Piperata BA, Murrieta RS, Wilson WM, Williams DD. Amazonian foods and implications for human biology. Ann Hum Biol. 2016; 43(4):330-48.

6. Yamaguchi KKL, Pereira LFR, Lamarão CV, Lima ES, Veiga-Junior VF. Amazon acai: chemistry and biological activities: a review. Food Chem. 2015; 179:137-51.

7. Portinho JA, Zimmermann LM, Bruck MR. Beneficial effects of açaí. International Journal of Nutrology. 2012; 5(1):15-20. 
8. Shukla S, Fu P, Gupta S. Apigenin induces apoptosis by targeting inhibitor of apoptosis proteins and Ku7O-Bax interaction in prostate cancer. Apoptosis. 2014; 19:883-94.

9. Dias MM, Noratto G, Martino HS, Arbizu S, Peluzio MC, Talcott S, et al. Pro-apoptotic activities of polyphenolics from açai (Euterpe oleracea Martius) in human SW-480 colon cancer cells. Nutr Cancer. 2014; 66:1394-405.

10. Silva DF, Vidal FC, Santos D, Costa MC, Morgado-Díaz J, Desterro SBNM, et al. Cytotoxic effects of Euterpe oleracea Mart. in malignant cell lines. BMC Complement Altern Med. 2014; 29:175.

11. Yoo S, Choi SY, You D, Kim CS. New drugs in prostate cancer. Prostate Int. 2016; 4:37-42.

12. Machado AK, Andreazza AC, da Silva TM, Boligon AA, do Nascimento V, Scola G, et al. Neuroprotective Effects of Açaí (Euterpe oleracea Mart.) against Rotenone In vitro Exposure. Oxid Med Cell Longev. 2016; 8940850.

13. Klimaczewski CV, Saraiva RDA, Roos DH, Boligon A, Athayde ML, Kamdem JP, et al. Antioxidant activity of Peumus boldus extract and alkaloid boldine against damage induced by Fe(II)-citrate in rat liver mitochondria in vitro. Industrial Crops and Products. 2014; 54:240-7.

14. O`Neill AJ, Prencipe M, Dowling C, Fan Y, Mulrane L, Gallagher WM, et al. Characterisation and manipulation of docetaxel resistant prostate cancer cell lines. Molecular Cancer. 2011; 10(126):1-13.

15. Fukui M, Yamabe N, Zhu BT. Resveratrol Attenuates the Anticancer Efficacy of Paclitaxel in Human Breast Cancer Cells In vitro and In Vivo. Eur. J. Cancer. 2010; 46(10):1882-91.

16. Azzolin VF, Cadona FC, Machado AK, Dal Berto M, Barbisan F, Dornelles EB, et al. Superoxide- hydrogen peroxide imbalance interferes with colorectal cancer cells viability, proliferation and oxaliplatin response. Toxicology In vitro. 2016; 8-15.

17. Cadoná FC, Rosa JL, Schneider T, Cubillos-Rojas M, Sánchez-Tena S, Azzolin VF, et al. Guaraná, a Highly Caffeinated Food, presents in vitro Antitumor Activity in Colorectal and Breast Cancer Cell Lines by Inhibiting AKT/mTOR/S6K and MAPKs Pathways. Nutr Cancer. 2017; 69:800-10.

18. Cubillos-Rojas M, Amair-Pinedo F, Peiró-Jordán R, Bartrons R, Ventura F, Rosa JL. The E3 Ubiquitin Protein Ligase HERC2 Modulates the Activity of Tumor Protein p53 by Regulating Its Oligomerization. J. Biol. Chem. 2014; 289:14782. 
19. Barbisan F, Motta Jde R, Trott A, Azzolin V, Dornelles EB, Marcon M, et al. Methotrexate-related response on human peripheral blood mononuclear cells may be modulated by the Ala16Val-SOD2 gene polymorphism. PLoS One. 2014; 9:e107299.

20. Zhou Y, Liu YE, Cao J, Zeng G, Shen C, Li Y, et al. Vitexins, nature-derived lignan compounds, induce apoptosis and suppress tumor growth. Clin Cancer Res. 2009; 15:5161-9.

21. Zhang Y, Seeram NP, Lee R, Feng L, Heber D. Isolation and identification of strawberry phenolics with antioxidant and human cancer cell antiproliferative properties. J Agric Food Chem. 2008; 56:670-5.

22. Spilioti E, Jaakkola M, Tolonen T, Lipponen M, Virtanen V, Chinou I, et al. Phenolic acid composition, antiatherogenic and anticancer potential of honeys derived from various regions in Greece. PLoS One. 2014; 9(4):e94860.

23. Jayasooriya RG, Kang SH, Kang CH, Choi YH, Moon DO, Hyun JW, et al. Apigenin decreases cell viability and telomerase activity in human leukemia cell lines. Food Chem Toxicol. 2014; 50:2605-11.

24. Erdogan S, Doganlar O, Doganlar ZB, Serttas R, Turkekul K, Dibirdik I, et al. A. The flavonoid apigenin reduces prostate cancer CD44(+) stem cell survival and migration through PI3K/Akt/NF-אB signaling. Life Sci. 2016; 162:77-86.

25. Shukla S, Fu P, Gupta S. Apigenin induces apoptosis by targeting inhibitor of apoptosis proteins and Ku7O-Bax interaction in prostate cancer. Apoptosis. 2014; 19:883-94.

26. Guo Y, Zhi F, Chen P, Zhao K, Xiang H, Mao Q, et al. Green tea and the risk of prostate cancer: A systematic review and meta-analysis. Medicine (Baltimore). 2017; 96:e6426.

27. Sorrenti V, Vanella L, Acquaviva R, Cardile V, Giofrè S, Di Giacomo C. Cyanidin induces apoptosis and differentiation in prostate cancer cells. Int J Oncol. 2015; 47:1303-10.

28. Seo Y, Ryu K, Park J, Jeon DK, Jo S, Lee HK, et al. Inhibition of ANO1 by luteolin and its cytotoxicity in human prostate cancer PC-3 cells. PLoS One. 2017; 12:e0174935.

29. Han K, Meng W, Zhang JJ, Zhou Y, Wang YL, Su Y, et al. Luteolin inhibited proliferation and induced apoptosis of prostate cancer cells through miR-301. Onco Target. 2016; 9:3085-94.

30. Wang L, Li W, Lin M, Garcia M, Mulholland D, Lilly M, et al. Luteolin, ellagic acid and punicic acid are natural products that inhibit prostate cancer metastasis. Carcinogenesis. 2014; 35:2321-30. 
31. Ferruelo A, de Las Heras MM, Redondo C, Ramón de Fata F, Romero I, Angulo JC. Wine polyphenols exert antineoplasic effect on androgen resistant PC-3 cell line through the inhibition of the transcriptional activity of COX-2 promoter mediated by NF-k $\beta$. Actas Urol Esp. 2014; 38:429-37.

32. Reddivari L, Vanamala J, Safe SH, Miller JC Jr. The bioactive compounds alpha-chaconine and gallic acid in potato extracts decrease survival and induce apoptosis in LNCaP and PC3 prostate cancer cells. Nutr Cancer. 2010; 62:601-10.

33. Lin HP, Lin CY, Huo C, Hsiao PH, Su LC, Jiang SS, et al. Caffeic acid phenethyl ester induced cell cycle arrest and growth inhibition in androgen-independent prostate cancer cells via regulation of Skp2, p53, p21Cip1 and p27Kip1.Oncotarget. 2015; 6:6684-707.

34. Sanderson JT, Clabault H, Patton C, Lassalle-Claux G, Jean-François J, Paré AF, et al. Antiproliferative, antiandrogenic and cytotoxic effects of novel caffeic acid derivatives in LNCaP human androgen-dependent prostate cancer cells. Bioorg Med Chem. 2013; 21:7182-93.

35. Tolba MF, Esmat A, Al-Abd AM, Azab SS, Khalifa AE, Mosli HA, et al. Caffeic acid phenethyl ester synergistically enhances docetaxel and paclitaxel cytotoxicity in prostate cancer cells. IUBMB Life. 2013; 65:716-29.

36. Zhou Y, Li Y, Zhou T, Zheng J, Li S, Li HB. Dietary Natural Products for Prevention and Treatment of Liver Cancer. Nutrients. 2016; 8(156).

37. Lam KY, Ling AP, Koh RY, Wong YP, Say YH. A Review on Medicinal Properties of Orientin. Adv Pharmacol Sci. 2016; 1:4104595.

38. An F, Wang S, Tian Q, Zhu D. Effects of orientin and vitexin from Trollius chinensis on the growth and apoptosis of esophageal cancer EC-109 cells. Oncol Lett. 2015; 10:2627-33.

39. Khan F, Sharma P, Prakash O, Shukla A, Vasudev PG, Luqman S, et al. Structure-Activity relationship studies on Holy Basil (Ocimum sanctum L.) based flavonoid orientin and its analogue for cytotoxic activity in liver cancer cell line HepG2. Comb Chem High Throughput Screen. 2016; 19:656-66.

40. Silva DA, Alves VG, Franco DM, Ribeiro LC, de Souza MC, Kato L, et al. Antiproliferative activity of Luehea candicans Mart. et Zucc. (Tiliaceae). Nat Prod Res. 2012; 26(4):364-9.

41. Silva ICV, Kaluderovic G, de Oliveira PF, Guimaraes DO, Quaresma CH, Porzel A, et al. Apoptosis caused by triterpenes and phytosterols and antioxidant activity of an enriched flavonoid extract and from Passiflora mucronata. Anticancer Agents Med Chem. 2018. 
Jobim ML et al.

42. Pei K, Ou J, Huang J, Ou S. $\rho$ - Coumaric acid and its conjugates: dietary sources, pharmacokinetic properties and biological activities. Journal of the Science of Food and Agriculture. 2016; 96 (9):2952-62.

43. Peng W, Wu JG, Jiang YB, Liu YJ, Sun T, Wu N, et al. Antitumor activity of 4-O-(2"-O-acetyl-6"-O- $\rho$-coumaroyl- $\beta$-D-glucopyrahosyl)- $\rho$ - coumaric acid against lung cancer via mitochondrial- mediated apoptosis. Chem Biol Interact. 2015; 25:8-13.

44. Marczylo TH, Cooke D, Brown K, Steward WP, Gescher AJ. Pharmacokinetics and metabolism of the pulative cancer chemopreventive agent cyaniding-3-glucoside in mice. Cancer Chemother Pharmacol. 2009; 64 (6):1261-8.

45. Sharma SH, Rajamanickam V, Nagarajan S. Antiproliferative effect of p-Coumaric acid targets UPR activation by downregulating Grp78 in colon cancer. Chem Biol Interact. 2018; 291:16-28.

46. Wang X, Wang G, Li X, Liu J, Hong T, Zhu Q, et al. Supression of rat and human androgen biosynthetic enzymes by apigenin: possible use for the treatment of prostate cancer. Fitoterapia. 2016; 111:66.

47. Chen XJ, Wu MY, Li DH, You J. Apigenin inhibits glioma cell growth through promoting microRNA-16 and suppression of BCL-2 and nuclear factor- kB/MM P-9. Mol Med Rep. 2016; 14 (3):2352-8.

48. Li Z, Zhang Y, Chen L, Li H. The dietary compound luteolin inhibits pancreatic cancer growth by targeting BCL-2. Food Funct. 2018; 9(5):3018-27. 